\title{
Ichthyofauna of selected water bodies and the Vistula River in Warsaw
}

\author{
Wiesław WIŚNIEWOLSKI and Janusz LIGIĘZA
}

\begin{abstract}
The Stanislaw Sakowicz Inland Fisheries Institute, River Fisheries Department, Główna 48, Żabieniec, 05-500 Piaseczno,Poland; e-mail:wieslaw.wisniewolski@gmail.com
\end{abstract}

\begin{abstract}
The ichthyofauna of the Warsaw section of the Vistula River as well as selected water bodies in Warsaw was described. The information was collected from catches, analysis of stocking registers as well as interviews with anglers carried out between 1989 and 2002. The existence of 40 fish species was noted, including 33 species in the Vistula River. 3 to 11 species, belonging to eurytopic and stagnophilic ecological guilds, was registered in particular water bodies. The results indicate that diversified fish assemblages exist in Warsaw water bodies that are subject to high anthropogenic pressure, including rich fish assemblages in the Vistula River.
\end{abstract}

Key words: ichthyofauna, Warsaw, the Vistula River, selected water bodies

\section{INTRODUCTION}

Warsaw, the largest city of Poland, covers the area of $517.9 \mathrm{~km}^{2}$ and is inhabited by almost 1.8 million people. It is located in the central part of the Masovian Plain, at the average elevation of 100 meters above sea level. The city borders embrace a section of the middle course of the Vistula River between $506.0 \mathrm{~km}$ and $528.7 \mathrm{~km}$. Its left-bank part is situated mostly on a high river escarpment, whereas the right-bank part lies mostly on the former floodplains.

During the last 300 years, the Vistula River changed its character from a meandering to braided river. This process was stipulated by an increase of variations in river discharges, caused by a decrease in water retention and an increase of erosion in the catchment area. The width of the watercourse of the Vistula in Warsaw does not usually exceed 230 meters during the average water level. The left bank is partly regulated in its section up to the Czerniakowski Port, and fully regulated from the Czerniakowski Port up to the Bielany district. The right bank is partly regulated throughout the entire Warsaw section of the river, mostly with transverse and longitudinal dams (Matuszkiewicz 2000).

Aside from the Vistula, which is the central waterway in Warsaw, many water bodies exist in its territory. These bodies can be divided into four basic categories: old river beds, ice formations (dead ice melting), ponds and moats, clay pit ponds. Old river beds and glacial lakes are natural formations, whereas other water bodies are man-made structures.

In majority, Warsaw water bodies are moderate-size reservoirs, usually not exceeding 10 ha. An exception to this rule is constituted by the Czemiakowskie, Wilanowskie and Kamionkowskie Lakes. The location of old river beds is connected with the Vistula icemarginal valley, whereas other reservoirs are located in various parts of the city. These reservoirs are subject to strong anthropopressure and are threatened by eutrophication. Despite negative effects, similarly to the Vistula River, relatively rich ichthyofauna can be found in other Warsaw water bodies (Borzęcka et al,. 2003, Prus 2004, Wiśniewolski 2005). Information referring to this ichthyofauna is rather fragmentary and can be found in various, often unpublished sources. The ichthyofauna of the Vistula River is best known, whereas the knowledge about fish inhabiting the water bodies in Warsaw is rather scarce. 
Warsaw is not an exception in this case, since the literature referring to the ichthyofauna of urban agglomerations is very scarce. At present, the Polish literature contains information on the ichthyofauna of water courses in Łódz (Kruk et al. 2003, 2005) as well as the Czerniejówka River in Lublin (Rechulicz 2008). Studies by Sumiński, describing fish species in Warsaw water bodies, date from the inter-war period $(1921,1922)$.

Deepening and updating the knowledge on fish that inhabit water bodies in urban agglomerations is important from the nature's point of view, as well as from the perspective of their exploitation through angling / fishing. This study is aimed at describing the ichthyofauna assemblages inhabiting the Vistula River as well as selected water bodies in Warsaw, on the basis of own catches, information required from the user of fish resources in these water bodies and interviews with anglers.

\section{STUDY AREA}

The Vistula River section in Warsaw is morphologically differentiated as a result of modifications that have occurred in the valley in connection with housing development, in the river bed in connection with hydrological constructions, as well as, to a certain extent resulting from the natural structure of the valley. Three sections can be distinguished:

1. First section is $43 \mathrm{~km}$ long (between 457 and $506 \mathrm{~km}$ ) and has a varied braided structure, with big, overgrown islands (islets) and scarce transverse dams and bank protections. The width of the riverbed ranges from 400 to $1100 \mathrm{~m}$ (Fig. 1: site 1).

2. Second section (between 506 and $525 \mathrm{~km}$ ) lies within Warsaw's city borders. Narrowed riverbed is regulated by several transverse dams on the right bank, whereas half of the length of the left bank is regulated with stone and concrete bank protection. The width of the riverbed ranges from 220 to $600 \mathrm{~m}$ (Fig. 1: site $2 \& 3$ ).

3. In its third section below Warsaw (at $526 \mathrm{~km}$ up to the Narew River mouth, $550 \mathrm{~km}$ ), the Vistula River has again a braided character; transverse dams and bank protections are scarce. The width of the riverbed ranges from 330 to $700 \mathrm{~m}$ (Backiel et al. 2000) (Fig. 1: site 4).

The Polish Angling Association - Mazovia District in Warsaw is the fish resources user of this section of the Vistula River. It also exploits some of the water bodies listed below, which are located within the city borders, or in its outskirts, and where the ichthyofauna studies were performed.

- The Czerniakowskie Lake is located in the Mokotów district, on a flood plain, at the foot of the so-called "Small Escarpment". This water body derives from an old river bed, created from old river bends cut off by land. The area of this water body amounts to $19.5 \mathrm{ha}$. Its average depth amounts to $2.0 \mathrm{~m}$ and maximum depth is $4.25 \mathrm{~m}$ (Fic \& Kręgiel 2004, Prus 2004) (Fig. 1: site 5).

- The Szczęśliwickie Lake is located in the Szczęśliwicki Park, in the Ochota district. It is a water body of anthropogenic origin, created through post-mining clay excavations being filled with water. This water body is composed of two connected reservoirs that occupy an area of 6.0 ha. The maximum depth of the Szczęśliwickie Lake amounts to $16.0 \mathrm{~m}$ (Borzęcka et al. 2003) (Fig. 1: site 6).

- The Kamionkowskie Lake is an old river bed of the Vistula, located in the northwestern part of the Praga-Poludnie district. Until the beginning of the 20th century it was directly connected with the Vistula River. At present, the modernised northern part is called the Praski Port and is separated from the lake by the National Stadium. The area of this water body is 8 ha. Its length amounts to $900 \mathrm{~m}$, whereas the width ranges from 100 to $150 \mathrm{~m}$ and the depth from 2 to $5 \mathrm{~m}$ (http://pl.wikipedia.org/wiki/Jeziorko_Kamionkowskie) (Fig. 1: site 7). 


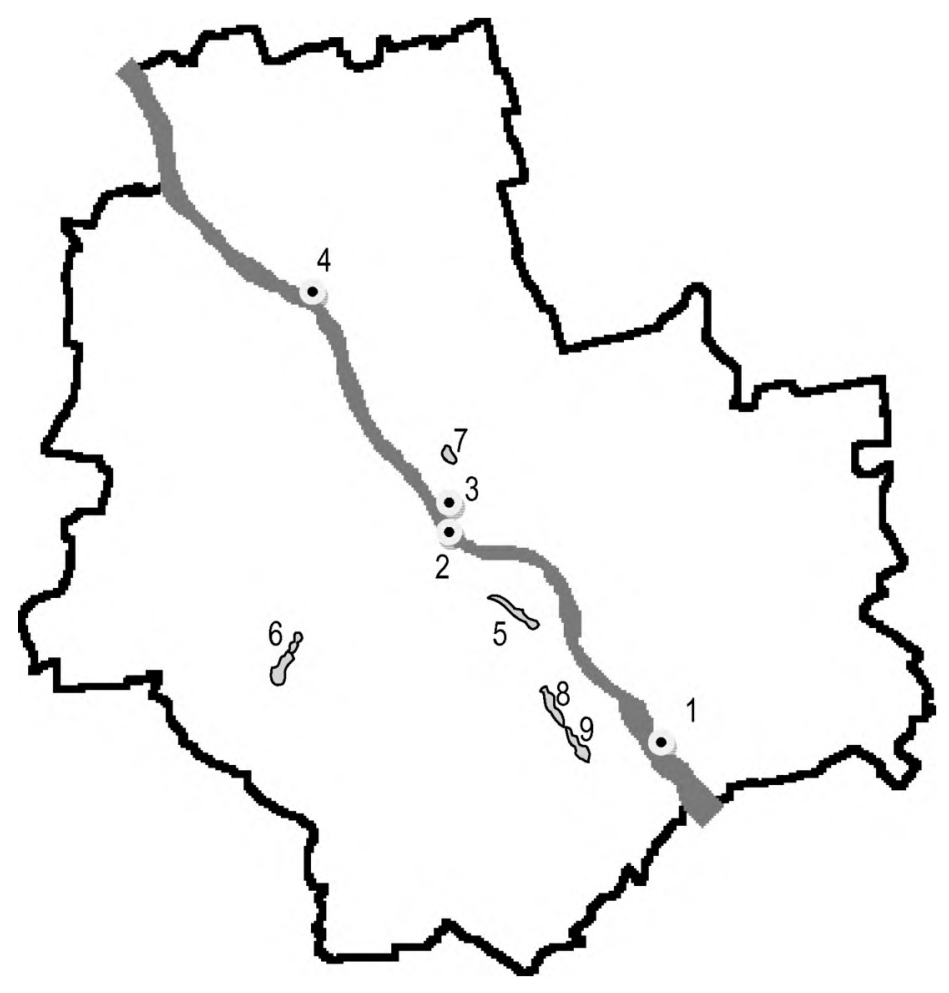

Fig. 1. Location of study sites in Warsaw; 1-4 - the Vistula River, 5 - the Czemiakowskie Lake, 6 - the Srçeśliwickie Lake, 7 - the Kamionkowskie Lake, 8 - the Wilanowskie Lake, 9 - the Powsinkowskie Lake.

- $\quad$ The Wilanowskie Lake is located in the Wilanów district, behind the Wilanowski Park. It is an old river bed, spreading over an area of 15.0 ha. Its average depth is approximately $1.5 \mathrm{~m}$ (Fig. 1: site 8). This water body is connected with the Powsinkowskie Lake (Fig. 1: site 9).

- The Powsinkowskie Lake is located more to the south, in Powsin. Similarly to the Wilanowskie Lake, it is an old river bed, spreading over an area of 8.5 ha.

There is no reliable information on the ichthyofauna of other water bodies in Warsaw.

\section{MATERIAL AND METHODS}

The information on the ichthyofauna found of Warsaw water bodies originates from control catches carried out with the use of electrofishing method (complemented by net catches) in the Vistula River in 1997 (Backiel et al. 2000) as well as in other water bodies: the Czerniakowskie Lake (1990, 1991, 1993 and 1999), the Szczęśliwickie Lake (2002), the Kamionkowskie Lake (1989), the Wilanowskie Lake (1990), the Powsinkowskie Lake (1990) (Table 1).

The captured fish were identified and grouped into particular species. The taxonomic classification was carried out according to Nelson's method (Brylińska 2000). Individuals were counted within one species, then weighted and measured. In the case of a large number of individuals, particular fish were measured and weighed in sub-tests. 
Table 1. Number of fish and species registered in the catches.

\begin{tabular}{|l|c|c|}
\hline \multicolumn{1}{|c|}{ Water body } & Number of fish & Number of species \\
\hline The Vistula River & $7068 / 197^{*}$ & 6 \\
The Kamionkowskie Lake & 178 & 5 \\
The Powsinkowskie Lake & 23 & 3 \\
The Wilanowskie Lake & 7 & 11 \\
The Szczęśliwickie Lake & 132 & 9 \\
The Czerniakowskie Lake & 143 & \\
\hline
\end{tabular}

Data on stockings carried out in these water bodies by the Polish Angling Association Mazovia District, as well as the results of inspections of angling catches, information enclosed in publications and interviews with anglers carried out in particular sites were also used as information on fish.

The classification into ecological reproductive guilds was done according to Balon's classification (1975) and the division into trophic guilds was done according to Opuszyński (1983). The division according to water flow preferences was done following the Schiemer \& Waidbacher (1992) method.

\section{RESULTS}

Experimental and control catches, analysis of stocking reports as well as interviews with anglers indicate considerable richness of fish species inhabiting water bodies in Warsaw. In total, 40 species were registered, out of which 30 species were identified on the basis of catches, 2 on the basis of the analysis of stocking reports and 11 on the basis of interviews (Table 2).

The information obtained from anglers indicated that also other species inhabit water bodies in Warsaw, such as loach, bitterling and sunbleak. Also nase, not identified in experimental catches was captured in the Vistula River in Warsaw, as well as sea trout, for which the Vistula is the migration corridor towards the Sub-Carpathian spawning grounds. In addition, three-spined stickleback and ten-spined stickleback can be found in water bodies and water courses in Warsaw. The existence of alien invasive species such as stone moroco, goad goby, Caspian sand goby, Amur sleeper and brown bullhead was also recorded.

Warsaw water bodies differed substantially in terms of the richness of fish species. With 33 species, the Vistula River was the richest water body: 24 species were identified in catches, 9 in registers and interviews. The number of species identified in other studied water bodies was lower and ranged from 3 to 11 . Bleak, roach and bream dominated in terms of the abundance of fish $(\% \mathrm{~N})$ in the Vistula River, whereas perch, roach, bream, rudd and Crucian carp dominated in the lakes (Table 3).

\section{ECOLOGICAL COMPOSITION}

With reference to water flow, three guilds with different preferences can be distinguished. The share of species belonging to particular ecological guilds in the total collection of 40 species registered in Warsaw water bodies (Table 2) was as follows: reophylic fish $-32.5 \%$, stagnophylic fish $-27.5 \%$, eurytopic fish $-35.0 \%$.

However, these relations were different when shares of these guilds were compared on the basis of the results of fish catches in particular water bodies (Table 4).

Reophylic species were found only in the Vistula River, where they were almost as abundant as the dominant eurytopic species. However, the group of stagnophylic fish was twice less abundant. The ichthyofauna in Warsaw lakes showed a different structure. There were no reophylic fish in the lakes, whereas stagnophylic and eurytopic guilds were represented. 
Fish species represented in Warsaw water bodies were characterised by different requirements in relation to the spawning time and place. The way of laying eggs also differed, thus permitting to differentiate the species, which form distinctive, ecological reproductive guilds (Table 5).

Table 2. Fish species found in water bodies in Warsaw.

\begin{tabular}{|c|c|c|c|c|}
\hline \multirow{2}{*}{ No. } & \multirow{2}{*}{ Species } & \multicolumn{3}{|c|}{ Source of information } \\
\hline & & Catches & Stocking & Interviews \\
\hline 1 & Goad goby Neogobius gymnotrachelus* & & & + \\
\hline 2 & Caspian sand goby Neogobius fluviatilis* & & & + \\
\hline 3 & Asp Aspius aspius & + & & \\
\hline 4 & Barbel Barbus barbus & + & & \\
\hline 5 & Vimba Vimba vimba & + & & + \\
\hline 6 & Ten-spined stickleback Pungitius pungitius & & & + \\
\hline 7 & Three-spined stickleback Gasterosteus aculeatus & + & & \\
\hline 8 & Stone moroco Pseudorasbora parva* & & & + \\
\hline 9 & Ruff Gymnocephalus cermutus & + & & \\
\hline 10 & Ide Leuciscus idus & + & & \\
\hline 11 & Dace Leuciscus leuciscus & + & & \\
\hline 12 & Crucian carp Carassius carassius & + & & \\
\hline 13 & Prussian carp Carassius gibelio & + & & \\
\hline 14 & Carp Cyprimus carpio * & + & & \\
\hline 15 & Gudgeon Gobio gobio & + & & \\
\hline 16 & White-finned gudgeon Gobio albipinnatus & + & & \\
\hline 17 & Chub Leuciscus cephalus & + & & \\
\hline 18 & Spined loach Cobitis taenia complex. & + & & \\
\hline 19 & White bream Abramis bjoerkna & + & & \\
\hline 20 & Bream Abramis brama & + & & \\
\hline 21 & Tench Tinca tinca & + & & \\
\hline 22 & Burbot Lota lota & + & & \\
\hline 23 & Perch Perca fluviatilis & + & & \\
\hline 24 & Loach Misgurnus fossilis & + & & + \\
\hline 25 & Roach Rutilus rutilus & + & & \\
\hline 26 & Bitterling Rhodeus sericeus & & & + \\
\hline 27 & Pikeperch Stizostedion lucioperca & + & & \\
\hline 28 & White-eyed bream Abramis sapa & + & & \\
\hline 29 & Sunbleak Leucaspius delineatus & & & + \\
\hline 30 & Wels Silurus glanis & + & & \\
\hline 31 & Brown bullhead Ictalurus nebulosus * & & & + \\
\hline 32 & Pike Esox lucius & + & & \\
\hline 33 & Stone loach Barbatula barbatula & + & & \\
\hline 34 & Nase Chondrostoma nasus & & & + \\
\hline 35 & Big head carp Aristichthys nobilis * & + & + & \\
\hline 36 & Amur sleeper Perccottus glenii* & + & & \\
\hline 37 & Sea trout Salmo trutta trutta & & & + \\
\hline 38 & Bleak Alburnus alburnus & + & & \\
\hline 39 & Eel Anguilla anguilla & & + & \\
\hline 40 & Rudd Scardinius erythrophthalmus & + & & \\
\hline
\end{tabular}

The Vistula River was characterised by the greatest diversity of ecological reproductive guilds. The information obtained through interviews shows that bitterling, representing the ostracophylic guild also occurs in the upper section of this river. In comparison with the Vistula River, ecological reproductive guilds in Warsaw lakes are less diverse. In this respect, the Powsinkowskie and the Wilanowskie Lakes are monotonous. Only the presence of phytophylic species was confirmed. In other lakes, aside of this guild, litho-phytophylic and litho-pelagophylic guilds were found. 
The representation of trophic guilds is more uniform in Warsaw water bodies. The same guilds have been identified in the Vistula River as well as in the Kamionkowskie, Szcześliwickie and Czerniakowskie Lakes. Less trophic guilds were discovered in the Powsinkowskie and Wilanowskie Lakes (Table 6).

Table 3. Abundance $(\% \mathrm{~N})$ of fish species registered in catches and their classification into ecological guilds; $\mathrm{N}-$ number of individuals, L - lithophylic species, L-F - litho-phytophylic species, F - phytophylic species, Ps psammophylic species, L-P - litho-pelagophylic species, $\mathrm{O}$ - ostracophylic species, D - predators, W-D - relative predators, B - invertebrates-eating species, W. - omnivorous species, R - herbivorous fish, P - plankton-eating fish; $\mathrm{Re}$ - reophylic species, St - stagnophylic species, Eu - eurytopic species;

* - Scardinius erythrophthalmus, Carassius gibelio, three-spined stickeback - Gasterosteus aculeatus (F, B, Eu), Gymnocephalus cernutus, barbel - Barbus barbus (L, B, Re), spined loach - Coblitis taenia complex (F, B, Eu), carp Cyprinus carpio, amur sleeper - Perccottus glenii (F, W-D, St), wels (Silurus glanis (F, D, Eu), white-eyed bream Abramis sapa (F, B, Re); ** - catches with nets.

\begin{tabular}{|c|c|c|c|c|c|c|c|c|c|c|c|}
\hline \multirow{3}{*}{$\mathrm{No}$} & \multirow{3}{*}{ Species } & \multicolumn{3}{|c|}{ Ecological guilds } & \multirow{3}{*}{\begin{tabular}{|c|}
$\begin{array}{c}\text { Kamion- } \\
\text { kowskie } \\
\text { Lake }\end{array}$ \\
$\% \mathrm{~N}$ \\
\end{tabular}} & \multirow{3}{*}{\begin{tabular}{|c|}
$\begin{array}{c}\text { Powsin- } \\
\text { kowskie } \\
\text { Lake }\end{array}$ \\
$\% \mathrm{~N}$ \\
\end{tabular}} & \multirow{3}{*}{\begin{tabular}{|c|}
$\begin{array}{c}\text { Wila- } \\
\text { nowskie } \\
\text { Lake }\end{array}$ \\
$\% \mathrm{~N}$ \\
\end{tabular}} & \multirow{3}{*}{\begin{tabular}{|c|}
$\begin{array}{c}\text { Szczęśli } \\
\text {-wickie } \\
\text { Lake }\end{array}$ \\
$\% \mathrm{~N}$ \\
\end{tabular}} & \multirow{3}{*}{\begin{tabular}{|c|}
$\begin{array}{c}\text { Czernia- } \\
\text { kowskie } \\
\text { Lake }\end{array}$ \\
$\% \mathrm{~N}$ \\
\end{tabular}} & \multirow{2}{*}{\multicolumn{2}{|c|}{ Vistula iver }} \\
\hline & & \multirow{2}{*}{\begin{tabular}{|c|}
$\begin{array}{c}\text { Repro- } \\
\text { ductiv } \\
\mathrm{e}\end{array}$ \\
\end{tabular}} & \multirow{2}{*}{$\begin{array}{l}\text { Tro- } \\
\text { phic }\end{array}$} & \multirow{2}{*}{$\begin{array}{l}\text { Water } \\
\text { flow }\end{array}$} & & & & & & & \\
\hline & & & & & & & & & & $\% \mathrm{~N}$ & $\% \mathrm{~N}^{* *}$ \\
\hline 1 & Bleak Alburnus alburnus & $\mathrm{F}$ & $\mathrm{B}$ & $\mathrm{Eu}$ & & & & & & 46.71 & \\
\hline 2 & Roach Rutilus rutilus & $\mathrm{F}$ & W & $\mathrm{Eu}$ & 5.62 & 34.78 & 42.86 & 11.4 & 25.87 & 22.41 & 0.51 \\
\hline 3 & Perch Perca fluviatilis & L-F & W-D & $\mathrm{Eu}$ & 73.03 & & & 52.3 & 14.69 & 14 & 1.02 \\
\hline 4 & Dace Leuciscus & & & & & & & & & & \\
\hline & leuciscus & L-F & B & $\operatorname{Re}$ & & & & & & 4.05 & \\
\hline 5 & Gudgeon Gobio gobio & Ps & B & $\operatorname{Re}$ & & & & & & 3.75 & \\
\hline 6 & Ide Leuciscus idus & L-F & $\mathrm{w}$ & $\operatorname{Re}$ & & & & & & 3.69 & 6.09 \\
\hline 7 & Vimba Vimba vimba & $\mathrm{L}$ & B & $\operatorname{Re}$ & & & & & & & 0.51 \\
\hline 8 & Pike Esox lucius & $\mathrm{F}$ & $\mathrm{D}$ & $\mathrm{Eu}$ & 3.37 & 4.35 & & 1.5 & 2.8 & 1.28 & \\
\hline 9 & Chub Leuciscus & & & Po & & & & & & 070 & \\
\hline 10 & Bream Abramis brama & $\begin{array}{l}\mathrm{L} \\
\mathrm{F}\end{array}$ & $\mathrm{W}$ & $\mathrm{Eu}$ & 14.04 & 30.43 & & & 3636 & 0.61 & 8528 \\
\hline 11 & White-finned gudgeon & & & & & & & & $50 . .00$ & & 03.20 \\
\hline & Gobio albipinnatus & Ps & B & $\operatorname{Re}$ & & & & & & 0.55 & \\
\hline 12 & Asp Aspius aspius & $\mathrm{L}$ & $\mathrm{D}$ & $\operatorname{Re}$ & & & & & & 0.38 & 1.02 \\
\hline 13 & Burbot Lota lota & L-P & W-D & $\operatorname{Re}$ & & & & & & 0.37 & \\
\hline 14 & White bream Abramis & & & & & & & & & & \\
\hline & bjoerkna & $\mathrm{F}$ & B & $\mathrm{Eu}$ & & & & 2.3 & 4.2 & 0.33 & 2.03 \\
\hline 15 & Stone loach Barbatula & & & & & & & & & & \\
\hline & barbatula & Ps & B & $\operatorname{Re}$ & & & & & & 0.26 & \\
\hline 16 & Pikepearch Stizostedion & & & & & & & & & & \\
\hline 17 & $\begin{array}{l}\text { lucioperca } \\
\text { Prussian carp Carassius }\end{array}$ & L-F & $\mathrm{D}$ & $\mathrm{Eu}$ & & & & & & 0.2 & \\
\hline & $\begin{array}{l}\text { Prussian carp carassius } \\
\text { gibelio }\end{array}$ & $\mathrm{F}$ & B & $\mathrm{St}$ & & & & 12.1 & & & 3.05 \\
\hline 18 & Eel Anguilla anguilla & L-P & W-D & St & & & & 6.1 & 2.8 & & \\
\hline 19 & Rudd Scardinius & & & & & & & & & & \\
\hline & erythrophthalmu & $\mathrm{F}$ & $\mathrm{W}$ & St & 0.56 & & 28.57 & 6.1 & & & \\
\hline 20 & Tench Tinca tinca & $\mathrm{F}$ & B & St & 3.37 & 17.39 & & 4.5 & 8.39 & & 0.51 \\
\hline 21 & Carp Cyprimus carpio & $\mathrm{F}$ & B & $\mathrm{Eu}$ & & & & 2.3 & 2.1 & & \\
\hline 22 & Ruff Gymnocephalus & & & & & & & & & & \\
\hline & cernuus & L-F & B & $\mathrm{Eu}$ & & & & 1.5 & & & \\
\hline $\begin{array}{l}23 \\
24\end{array}$ & $\begin{array}{l}\text { Crucian carp Carassius } \\
\text { carassius } \\
\text { Others* }\end{array}$ & $\mathrm{F}$ & B & St & & 13.04 & 28.57 & 0.8 & 2.8 & $*$ & \\
\hline
\end{tabular}

The information obtained from interviews proves the existence of herbivorous nase in the Vistula River and plankton-eating sunbleak in the lakes. This contributes to the richness of trophic groups of the ichthyofauna of Warsaw water bodies. 


\section{PROTECTED SPECIES}

Among fish inhabiting Warsaw water bodies, some species are subject to strict or partial protection (Table 7). Some endangered species are listed in the Red Book of Endangered Species, as well as in Annexes II and V of the Habitats Directive.

Vimba is considered a critically endangered species, whereas nase is an endangered species. Another five species (barbell, white-finned gudgeon, burbot, loach, bitterling) are considered vulnerable to extinction and asp, dace, crucian carp, white-eyed bream and wels are near threatened species. Sea trout and eel are conservation dependent species. The remaining species are not threatened and are considered as least concern species. Barbel, white-finned gudgeon, loach, bitterling and asp are listed in Annex II and V of the Habitats Directive and thus protected under the European ecological network Natura 2000. White-finned gudgeon, loach, bitterling, spined loach and stone loach are subject to species protection under the Polish legislation.

Table 4. Percentage share of fish guilds with different water flow preferences in Warsaw water bodies (on the basis of catch results - Table 3 ).

\begin{tabular}{|l|c|c|c|c|}
\hline \multirow{2}{*}{ Water body } & Number of species & \multicolumn{3}{|c|}{ Water flow preferences (\% N) } \\
\cline { 3 - 5 } & $\mathrm{N}=100 \%$ & Reophylic fish & Stagnophilic fish & Eurytopic fish \\
\hline Vistula River & 28 & 39.3 & 17.9 & 42.9 \\
Kamionkowskie Lake & 6 & 0.0 & 33.3 & 66.7 \\
Powsinkowskie Lake & 5 & 0.0 & 40.0 & 60.0 \\
Wilanowskie Lake & 3 & 0.0 & 66.7 & 33.3 \\
Szczęśliwickie Lake & 11 & 0.0 & 45.5 & 54.5 \\
Czerniakowskie Lake & 9 & 0.0 & 33.3 & 66.7 \\
\hline
\end{tabular}

Table 5. Percentage share of fish guilds representing different ecological reproductive guilds in Warsaw water bodies (on the basis of catch results - Table 3 ).

\begin{tabular}{|c|c|c|c|c|c|c|}
\hline \multirow[b]{2}{*}{ Water body } & \multirow[b]{2}{*}{$\begin{array}{c}\text { Number of } \\
\text { species } \\
N=100 \%\end{array}$} & \multicolumn{5}{|c|}{ Ecological reproductive guilds (\% N) } \\
\hline & & $\begin{array}{c}\text { Lithophylic } \\
\text { fish }\end{array}$ & $\begin{array}{c}\text { Litho- } \\
\text { phytophylic } \\
\text { fish }\end{array}$ & $\begin{array}{c}\text { Phyto-phylic } \\
\text { fish }\end{array}$ & $\begin{array}{l}\text { Psammo- } \\
\text { phylic fish }\end{array}$ & $\begin{array}{c}\text { Litho- } \\
\text { pelagophylic } \\
\text { fish }\end{array}$ \\
\hline Vistula River & 28 & 14.3 & 17.9 & 53.6 & 10.7 & 7.1 \\
\hline Kamionkowskie Lake & 6 & & 16.7 & 83.3 & & \\
\hline Powsinkowskie Lake & 5 & & & 100.0 & & \\
\hline Wilanowskie Lake & 3 & & & 100.0 & & \\
\hline Szczęśliwickie Lake & 11 & & 18.2 & 72.7 & & 9.1 \\
\hline Czerniakowskie Lake & 9 & & 11.1 & 77.8 & & 11.1 \\
\hline
\end{tabular}

Table 6. Percentage share of fish guilds representing different trophic guilds in Warsaw water bodies (on the basis of catch results - Table 3 ).

\begin{tabular}{|l|c|c|c|c|c|}
\hline \multirow{2}{*}{ Water body } & \multirow{2}{*}{$\begin{array}{c}\text { Number } \\
\text { of species }\end{array}$} & \multicolumn{4}{|c|}{ Ecological reproductive guilds (\% N) } \\
\cline { 3 - 6 } & N=100\% & predators & $\begin{array}{c}\text { relative } \\
\text { predators }\end{array}$ & $\begin{array}{c}\text { invertebrates- } \\
\text { eating fish }\end{array}$ & omnivorous fish \\
\hline Vistula River & 28 & 16.7 & 10.7 & 60.7 & 14.3 \\
Kamionkowskie Lake & 6 & 16.7 & 16.7 & 33.3 & 33.3 \\
Powsinkowskie Lake & 5 & 20.0 & & 60.0 & 20.0 \\
Wilanowskie Lake & 3 & & & 33.3 & 66.7 \\
Szczęśliwickie Lake & 11 & 9.1 & 18.2 & 54.5 & 18.2 \\
Czerniakowskie Lake & 9 & 11.1 & 22.2 & 55.6 & 11.1 \\
\hline
\end{tabular}


Until the middle of the $20^{\text {th }}$ century, the Vistula River constituted the main spawning migration route for vimba, Atlantic salmon, sea trout and Baltic sturgeon. Following the construction of the Wloclawek dam and also due to drastic worsening of water quality, Baltic sturgeon and salmon became extinct and the populations of sea trout and vimba decreased considerably. At present, efforts aimed at restitution of these species have been undertaken and hopefully the abundance of these populations will also increase in the Warsaw section of the Vistula River.

Table 7. Risk categories and protection status of fish species inhabiting Warsaw water bodies (according to Witkowski et al. 2009); OG - species protection in Poland, DS. II - species listed in Annex II of the Habitats Directive, DS. V species listed in Annex V of the Habitats Directive; - no protection.

\begin{tabular}{|c|c|c|}
\hline $\begin{array}{c}\text { Risk categories } \\
\text { according IUCN } 2001 \text { criteria }\end{array}$ & Species & Protection status \\
\hline Critically endangered species (CR) & Vimba Vimba vimba & - \\
\hline Endangered species (EN) & Nase Chondrostoma nasus & - \\
\hline Vulnerable species (VU) & $\begin{array}{l}\text { Barbel Barbus barbus } \\
\text { White-finned gudgeon Gobio albipinnatus } \\
\text { Burbot Lota lota } \\
\text { Loach Misgurnus fossilis } \\
\text { Bitterling Rhodets sericeus }\end{array}$ & $\begin{array}{c}\text { DS. V } \\
\text { OG, DS. II } \\
- \\
\text { OG, DS. II } \\
\text { OG, DS. II } \\
\end{array}$ \\
\hline Near threatened species (NT) & $\begin{array}{l}\text { Asp Aspius aspitus } \\
\text { Dace Leuciscus leuciscus } \\
\text { Crucian carp Carassius carassius } \\
\text { White-eyed bream Abramis sapa } \\
\text { Wels Silurus glanis } \\
\end{array}$ & $\begin{array}{c}\text { DS. II, DS. V } \\
- \\
- \\
- \\
- \\
\end{array}$ \\
\hline $\begin{array}{l}\text { Conservation dependent species } \\
\text { (CD) }\end{array}$ & $\begin{array}{l}\text { Sea trout Salmo trutta trutta } \\
\text { Eel Anguilla anguilla }\end{array}$ & - \\
\hline Least concern species (LC) & $\begin{array}{l}\text { Three-spined stickleback Gasterosteus aculeatus } \\
\text { Ten-spined stickleback Pungitius pungitius } \\
\text { Ruff Gymnocephalus cernuus } \\
\text { Ide Leuciscus idus } \\
\text { Prussian carp Carassius gibelio } \\
\text { Common carp Cyprinus carpio } \\
\text { Gudgeon Gobio gobio } \\
\text { Chub Leuciscus cephalus } \\
\text { Spined loach Cobitis taenia complex } \\
\text { White bream Abramis bjoerkna } \\
\text { Bream Abramis brama } \\
\text { Tench Tinca tinca } \\
\text { Perch Perca fluviatilis } \\
\text { Roach Rutilus rutilus } \\
\text { Pikeperch Stizostedion lucioperca } \\
\text { Sunbleak Leucaspius delineatus } \\
\text { Pike Esox lucius } \\
\text { Stone loach Barbatula barbatula } \\
\text { Bleak Alburnus alburnus } \\
\text { Rudd Scardinius erythrophthalmus }\end{array}$ & $\begin{array}{c}- \\
- \\
- \\
- \\
- \\
- \\
- \\
- \\
\text { OG } \\
- \\
- \\
- \\
- \\
- \\
- \\
- \\
- \\
\text { OG } \\
- \\
-\end{array}$ \\
\hline Alien species & $\begin{array}{l}\text { Goad goby Neogobius gymnotrachelus } \\
\text { Caspian sand goby Neogobius fluviatilis } \\
\text { Stone moroco Pseudorasbora parva } \\
\text { Brown bullhead Ictalurus nebulosus } \\
\text { Big head carp Aristichthys nobilis } \\
\text { Amur sleeper Perccottus glenii }\end{array}$ & $\begin{array}{l}- \\
- \\
- \\
-\end{array}$ \\
\hline
\end{tabular}


SPECIES REVIEW

40 fish species registered in Warsaw water bodies belong to 12 families. Two - Gobidae and Odontobutidae cover 3 alien species: Caspian sand goby and goad goby as well as amur sleeper. Stone moroco and big head carp, that belong to Cyprinidae, are also considered to be alien species. Notwithstanding their alien origin, the Prussian carp, white-eyed bream and carp, that belong to Cyprinidae family, have become a permanent element of the ichthyofauna. Other species are considered to be autochthonic. The characteristics of each species is presented below.

\section{Anguillidae}

Sites: $5,6,7$.

$$
\text { Eel - Anguilla anguilla (L., 1758) }
$$

Very rare in Warsaw water bodies. The construction of the Wloclawek dam has broken the migratory route of eel. Captured individuals came from stockings performed by the Polish Angling Association.

Esocidae

Sites: $1-9$.

$$
\text { Pike - Esox Iucius (L., 1758) }
$$

Pike is the main predator inhabiting all studied Warsaw water bodies.

Percidae

Sites: $1-9$.

$$
\text { Perch - Perca fluviatilis (L., 1758) }
$$

Numerous occurrence of this species was noted in all study sites.

Sites: $1-4,5,6,7$.

$$
\text { Pikeperch - Stizostedion lucioperca (L., 1758) }
$$

The occurrence of pikeperch was noted in the Vistula River study sites (catches with nets), in the Szczęśliwickie Lake (data on stockings carried out by the Polish Angling Association) as well as in the Kamionkowskie and the Czerniakowskie Lakes (direct interviews with anglers).

Siluridae

Sites: $1-4,5,6$.

$$
\text { Wels - Silurus glanis (L., 1758) }
$$

Wels is at present the biggest fish inhabiting Warsaw water bodies. Its presence was noted in catches with nets carried out in the Vistula River. The Polish Angling Association performed stockings in the Szczęśliwickie and the Czerniakowskie Lakes.

Cyprinidae

Sites: 1-9.

$$
\text { Carp - Cyprinus carpio (L., 1758) }
$$

This species inhabits all studied water bodies within the Warsaw's borders. The occurrence of carp in lakes is strongly linked with stockings. Natural spawning is rarely successful in Polish conditions. 
Sites: $5,6,7,8,9$.

$$
\text { Crucian carp - Carassius carassius (L., 1758) }
$$

Rare in all studied Warsaw lakes. This species was not registered in the Vistula River.

Sites: $1-4,5,6,8,9$.

$$
\text { Prussian carp - Carassius gibelio (Bloch 1783) }
$$

The occurrence of this species was noted in catches with nets in the Vistula River. Direct interviews with anglers confirmed that Prussian carp appears also in the Powsinkowskie, Wilanowskie, Szczęśliwickie and Czerniakowskie Lakes. Prussian carp was not registered in the Kamionkowskie Lake.

Sites: $1-9$.

$$
\text { Tench - Tinca tinca (L., 1758) }
$$

The occurrence of tench was registered in the catches with nets in the Vistula River as well as in electrofishing catches in the Kamionkowskie, Powsinkowskie, Szczęśliwickie and Czerniakowskie Lakes. Direct interviews with anglers confirmed that tench occurs also in the Wilanowskie Lake.

Sites: $1-4$.

$$
\text { Vimba - Vimba vimba (L., 1758) }
$$

The occurrence of certa in the Vistula River was noted on the basis of catches with nets and interviews with anglers. Large numbers of fish of the migratory form of certa had entered the Vistula River but the construction of the Wloclawek dam made the migration practically impossible and has led to a total disappearance of this migratory stock.

Sites: $1-4$.

$$
\text { Nase - Chondrostoma nasus (L., 1758) }
$$

Interviews with anglers confirmed the occurrence of this species in the Vistula River in Warsaw.

\section{Sites: $1-4$.}

$$
\text { Barbel - Barbus barbus (L., 1758) }
$$

Few barbels were registered in electrofishing catches carried out in the Vistula River. It is regularly captured in the river by anglers. The species is listed in Annex V of the Habitats Directive.

Sites: $1-4$.

$$
\text { Asp - Aspius aspius (L., 1758) }
$$

This species was registered both in electrofishing catches and in net catches carried out in the Vistula River in Warsaw. The species is listed in Annex II and Annex V of the Habitats Directive.

Sites : $1-4,5$.

$$
\text { Ide - Leuciscus idus (L., 1758) }
$$

The occurrence of ide was noted in electrofishing catches and net catches carried out in the Vistula River. Data from stockings provided by the Polish Angling Association shows that ide also exists in the Czerniakowskie Lake.

Sites: 1-4.

$$
\text { Chub - Leuciscus cephalus (L., 1758) }
$$

Chub appeared only in electrofishing catches carried out in the Vistula River. 
Sites: $1-4$.

$$
\text { Dace - Leuciscus leuciscus (L., 1758) }
$$

Dace appeared only in electrofishing catches carried out in the Vistula River.

Sites: $1-4,5,7,9$.

$$
\text { Bream - Abramis brama (L., 1758) }
$$

The occurrence of bream was registered in the electrofishing catches carried out in the Kamionkowskie, Powsinkowskie, Czerniakowskie Lakes and the Vistula River. It was the dominant species in the net catches carried out in the Vistula River.

Sites: $1-4,5,6,7,9$.

$$
\text { White bream - Abramis bjoerkna (L., 1758) }
$$

White bream was registered in the electrofishing catches carried out in the Szczęśliwickie and Czerniakowskie Lakes as well as in the Vistula River. It also occurred in the net catches. Interviews with anglers also confirm the occurrence of white bream in the Kamionkowskie and Powsinkowskie Lakes. White bream was not registered in the Wilanowskie Lake.

Sites: $1-4$.

$$
\text { White-eyed bream - Abramis sapa (Pallas, 1811) }
$$

White-eyed bream is a species that originates from the Black Sea. It has appeared in the Bug and Vistula river systems for many years, but earlier had not been differentiated from bream. The occurrence of this species was registered in electrofishing catches carried out in the Vistula River.

Sites: $1-9$.

$$
\text { Roach - Rutilus rutilus (L., 1758) }
$$

Numerous occurrence of this species was noted in all study sites. Only in the Kamionkowskie Lake, roach did not belong to the dominant species.

\section{Sites: $1-9$.}

$$
\text { Rudd - Scardinius erythrophthalmus (L., 1758) }
$$

The electrofishing catches and the interviews with anglers prove that this species exists in all studied Warsaw Lakes, as well as in the Vistula River.

Sites: $1-4,5,7,8,9$.

$$
\text { Bleak - Alburnus alburnus (L., 1758) }
$$

Bleak was the dominant species in terms of numbers in the electrofishing catches carried out in the Vistula River. The interviews with anglers prove that this species also exists in the Kamionkowskie, Powsinkowskie, Wilanowskie and Czerniakowskie Lakes. Bleak was not registered in the Szczęśliwickie Lake.

Sites: 8,9 .

$$
\text { Sunbleak - Leucaspius delineatus (Heckel, 1843) }
$$

The occurrence of sunbleak in the studied sites was only noted on the basis of interviews with anglers.

Sites: $1-4,5,8,9$.

$$
\text { Bitterling - Rhodeus sericeus (Pallas, 1776) }
$$

The occurrence of bitterling in the studied sites was only noted on the basis of interviews with anglers. Listed in Annex II of the Habitats Directive. Under protection in Poland. 
Sites: $1-4$.

$$
\text { Gudgeon - Gobio gobio (L., 1758) }
$$

This species occurred uniquely in the electrofishing catches carried out in the Vistula River.

Sites: $1-4$.

$$
\text { White-finned gudgeon - Gobio albipinnatus (Luksch, 1933) }
$$

This species occurred rarely in the electrofishing catches carried out in the Vistula River. Listed in Annex II of the Habitats Directive. Under protection in Poland.

\section{Sites: 5 .}

$$
\text { Big head carp - Aristichthys nobilis (Valenciennes, 1844) }
$$

The occurrence of big head carp in the Czerniakowskie Lake was noted on the basis of the data from the Polish Angling Association and the interviews with anglers.

\section{Site: 5 .}

\section{Grass carp - Ctenopharyngodon idella (Valenciennes, 1844)}

The occurrence of grass carp in the Czerniakowskie Lake was noted on the basis of interviews with anglers.

Sites: $1-4$.

$$
\text { Stone moroco - Pseudorasbora parva (Schlegel, 1842) }
$$

The occurrence of this species in the Vistula River was noted on the basis of interviews with anglers.

\section{Cobitidae}

$$
\text { Spined loach - Cobitis taenia complex (L., 1758) }
$$

The occurrence of spined loach in the Vistula River was registered on the basis of electrofishing catches. Under protection in Poland.

Sites: $1-4$.

$$
\text { Loach - Misgurnus fossilis (L., 1758) }
$$

The occurrence of loach in the Vistula River was registered on the basis of interviews with anglers. Listed in Annex II of the Habitats Directive. Under protection in Poland.

Balitoridae

Sites: $1-4$.

$$
\text { Stone loach - Barbatula barbatula (L., 1758) }
$$

The occurrence of stone loach in the Vistula River was registered on the basis of electrofishing catches. Under protection in Poland.

\section{Gadidae}

\section{Sites: 1-4.}

$$
\text { Burbot - Lota lota (L., 1758) }
$$

The occurrence of burbot in the Vistula River was registered on the basis of electrofishing catches. 
Gasterosteidae

Sites: $1-4,5,8,9$.

Three-spined stickleback- Gasterosteus aculeatus (L., 1758)

This species was noted in the electrofishing catches carried out in the Vistula River. In the Powsinkowskie, Wilanowskie and Czerniakowskie Lakes noted by anglers.

Sites: 8,9 .

$$
\text { Ten-spined stickleback - Pungitius pungitius (L., 1758) }
$$

The occurrence of ten-spined stickleback in the Powsinkowskie and Wilanowskie Lakes was noted on the basis of interviews with anglers.

Odontobutidae

Sites: $1-4$.

$$
\text { Amur sleeper - Perccottus glenii (Dybowski, 1877) }
$$

The occurrence of amur sleeper was noted in the electrofishing catches carried out in the Vistula River.

Gobiidae

Sites: $1-4$.

Caspian sand goby - Neogobius fluviatilis (Pallas, 1811)

The occurrence of Caspian sand goby in the Vistula River was registered on the basis of interviews with anglers.

Sites: $1-4$.

$$
\text { Goad goby - Neogobius gymnotrachelus (Kessler, 1857) }
$$

The occurrence of goad goby in the Vistula River was registered on the basis of interviews with anglers.

Salmonidae

Sites: $1-4$.

$$
\text { Sea trout - Salmo trutta trutta (L., 1758) }
$$

The occurrence registered on the basis of interviews with anglers.

Sites: $1-4$.

$$
\text { Salmon - Salmo salar (L., 1758) }
$$

Historical occurrence. The species listed in Annex II of the Habitats Directive. Covered by a restitution programme.

Acipenseridae

Sites: $1-4$.

$$
\text { Baltic sturgeon - Acipenser oxyrhynchus (Mitchill, 1815) }
$$

Historical occurrence. The species listed in Annex II of the Habitats Directive (western sturgeon). Covered by a restitution programme. 


\section{DISCUSSION}

\section{Species richness}

On the basis of catches, analysis of stocking reports as well as interviews with anglers, the occurrence of 33 fish species was registered in the Warsaw section of the Vistula River. Together with the ichthyofauna of the studied Warsaw lakes, 40 species, belonging to 12 families occurred in Warsaw water bodies. It is a considerable number, taking into account that 58 species of local, freshwater ichthyofauna occur in Poland (Witkowski et al. 2009).

In the inter-war period, the Warsaw section of the Vistula River was inhabited by 34 fish species. The ichthyofauna species composition in the beginning of the $20^{\text {th }}$ century differed from the present one. Among fish which inhabited this section of the river and which have not been registered in the studies currently carried out, the following species were mentioned: bullhead Cottus gobio (L., 1758), flounder Pleuronectes flesus (L., 1758), sabre carp Peleus cultratus (L., 1758), silver bream Aramis ballerus (L., 1758), Atlantic salmon, Western sturgeon Acipenser sturio (L., 1758). The occurrence of sea lamprey Petromyzon marines (L., 1758) was also noted (Sumiński 1922). The ichthyofauna of Warsaw water bodies was poorer than at present and was restricted to such species as crucian carp, bitterling, three-spined stickleback, sunbleak, carp and ide (Sumiński, Tenenbaum 1921).

In the catchment of Jasien and Lódka Rivers (streams flowing through the second largest city in Poland after Warsaw - Łódź), only 9 fish species were noted. Small species dominated such as three-spined stickleback, gudgeon and stone loach. Also the presence of alien species such as stone moroco and Prussian carp were registered (Kruk et al. 2003). In the catchment of the Sokolowka River, located within the borders of the city of Lódz, also 9 fish species were registered (Kruk et al. 2005). In total, 11 fish species were registered in the streams flowing through Łódź.

28 fish and lamprey species, belonging to 9 families, were identified in the water bodies of the Lomżyński Landscape Park in the Narew River Valley. Aside common species, also those covered by species protection were registered, namely Ukrainian brook lamprey, bitterling, stone loach, spined loach and loach (Wiśniewolski et al. 1999). In 1967-1968, Bontemps \& Rudnicki (1968) captured 18 fish species in the upper Narew River near Siemianówka and informed about another three species appearing in the net catches. More than ten years after, Sych et al. (1990), discovered 15 species near Uhowo, in the Narew River, whereas, according to Penczak et al. (1990a), 24 fish species and one lamprey species were found in the entire section of the river, from the Siemianówka reservoir to the backwater of the Zegrzyński Reservoir. The fish assemblage in the Narew River, within the borders of the Narwianski Landscape Park, was composed of 18 species in the watercourse (Wiśniewolski i in. 2004a), whereas in the Biebrza River and its tributaries 36 species were identified (Witkowski 1984). The studies carried out in this river system 20 years later proved the occurrence of only 24-26 fish species (Wiśniewolski et al. 2004b). In the River Bug system, connected to the Narew River, altogether 3 lamprey species and 44 fish species were identified: 35 native species and 9 deliberately introduced or accidentally introduced species (Danilkiewicz 1997). Also the Pilica River basin was rich in species, since 38 of them were identified in this area, including one lamprey species (Penczak 1988). The Vistula River was similarly rich in fish species near Kozienice, where 38 taxons were identified (Nabiałek 1984). In the Bzura River, where no fish had been found for many years, after the pollutant influx from the Lódź agglomeration was stopped, the dynamic, natural recovery process of the ichthyofauna took place and at the turn of the $20^{\text {th }}$ and $21^{\text {st }}$ century 22 fish species were registered (Penczak et al. 2000). 


\section{Ecological composition}

The structure of ecological guilds established by fish species is interesting in relation to the considerable number of fish species found in Warsaw water bodies. The guilds are composed of species characterised by common, specific requirements, thus permitting the adaptation to environmental conditions. The lakes in Warsaw are above all the habitats of stagnophilic species and the accompanying eurytopic species, representing the phytophylic and lithophytophylic reproductive guilds. In this respect, the Vistula River is a considerably richer habitat. 33 registered species represent all ecological guilds and that gives evidence of high ecological diversity of this ecosystem.

The presence of different types of habitats is important for the occurrence of particular ecological guilds. The Lojewek River was a refuge for lithophylic (4.7 and 34.2\%) and psammophylic (38.5 and 39.7\%) species in the Lomżyński Landscape Park in the Narew River Valley. The share of lithophylic species was small $(0.53 \%)$ in the Narew River water-bed. Similarly to old river beds, phytophylic and litho-phytophylic species dominated in this river. Stagnant waters of the Narwica River constituted a habitat for the protected bitterling (2.68\%) (Wiśniewolski et al. 1999). Different shares of typically riverine lithophylic species were also registered in other watercourses of the Narew River basin. In the Supraśl River basin 6 lithophylic species constituted $24.3 \%$ of the fish and lamprey assemblage (Penczak et al. 1991a). In the left-bank tributaries of the Narew River the share of litophylic species was much smaller, as these fish constituted only 6.4\% of ichthyofauna assemblage (Penczak et al. 1991b). The situation in the Narew tributaries on the Kurpiowska Plain was better. Here, similarly to the Supraśl River, 6 lithophylic species were registered, and their share amounted to $28 \%$ (Penczak et al. 1992). In the Vistula River, near Kozienice, 10 reophylic species, constituting $15.01 \%$ of the total number of captured fish, 2 species of stagnophylic fish, that is $0.03 \%$ and 19 species of eurytopic fish $-84.96 \%$ (Nabiałek 1984) were captured. In comparison, in the Narew River watercourse in the Narwiański Landscape Park 5 species of reophylic fish, constituting $9.00 \%$ of the total number of captured fish, 1 stagnophylic species $-0.97 \%$ and 12 species of eurytopic fish $-90.03 \%$ were captured (Wiśniewolski et al. 2004a). In the Bzura River, 7 reophylic fish species were registered, constituting $11.80 \%$ of all captured species, 2 stagnophylic species $-1.00 \%$ and 13 eurytopic fish species $-87.20 \%$ were captured (Penczak et al. 2000).

\section{Endangered and alien species}

In the Vistula River in Warsaw, endangered, vulnerable or near threatened species were represented by 9 species. In comparison, in the Vistula River near Kozienice, 11 species (Nabialek 1984) and in the Bzura River 3 species (Penczak et al. 2000) belonging to this group were registered. In the Narew River, in the Narwiański Landscape Park 4 endangered species were captured in the watercourse, whereas in the Biebrza River their number reached 13 species (Wiśniewolski et al. 2004b).

Alien species in the Vistula River in Warsaw were represented by 5 species. In comparison, in the Vistula River near Kozienice 2 alien species had been noted (Nabiałek 1984), however this status changed in the beginning of the eighties and according to current studies the list should be completed with amur sleeper, goad goby and Caspian sand goby. 2 alien species were registered in the Bzura River (Penczak et al. 2000). In the Biebrza River alien fish belonged to 4 species (Wiśniewolski et al. 2004b), whereas no alien species were found in the Narew River (Wiśniewolski et al. 2004a).

In total, 22 fish species were identified in all Warsaw lakes (Borzęcka et al. 2003, data from the Polish Angling Association). The presence of ide, a reophylic species that had been 
registered in the past, was not confirmed (Sumiński, Tenenbaum 1921). In comparison, in the old, closed river beds of the Narew River in the Narwianski Landscape Park the occurrence of 12 species was observed, whereas 10 species were registered in the old, closed river beds of the Biebrza River in the Biebrzański National Park (Wiśniewolski et al. 2004 a, b).

The ichthyofauna of the Vistula River in Warsaw can be considered as rich. The diversity of ecological fish guilds that constitute this ichthyofauna confirms that great habitat diversity of the Vistula River ecosystem has been preserved. In comparison, the ichthyofauna of Warsaw lakes is much poorer. It relates the limnic conditions of these ecosystems and is similar to the ichthyofauna registered in the old closed river-beds of the Biebrza and Narew. This study only identifies the ichthyofauna of the Vistula River and the biggest, selected, Warsaw lakes. Therefore, an increase in the number of species inhabiting the waters of this agglomeration is to be expected as new studies aimed at identifying the fish stocks of the remaining water bodies in Warsaw proceed.

\section{CONCLUSIONS}

1. 40 fish species were identified in Warsaw water bodies, including 10 endangered, vulnerable or near threatened species, as well as 8 alien species.

2. Eurytopic fish were recognised as the most common species: roach, perch, bream, carp and pike were observed both in the Vistula River and in most of the studied water bodies.

3. Roach, bream and perch originate from natural spawning, carp comes from stockings performed by the user of fish resources in these waters, whereas pike originates from natural spawning in most water bodies, but it is supported by stockings.

4. The presence of stagnophylic and eurytopic species is typical for the studied lakes, so is the lack of reophylic species.

5. Reophylic species such as barbel, dace, ide, chub, asp and gudgeon, stone loach and burbot were present in the Vistula River ichthyofauna. Eurytopic species such as bleak, roach, bream, perch and white bream also occupied an important position.

6. The attention should also be paid to the fish species, inhabiting Warsaw water bodies, that are covered by species protection, namely bitterling, loach, white-finned gudgeon, stone loach. Species protected in the framework of the European ecological network Natura 2000 are also among fish that inhabit Warsaw water bodies, namely asp, white-finned gudgeon, loach and bitterling. Also the Atlantic salmon, undergoing restitution in the Vistula River basin, is part of these species, as well as diadromous migratory fish species such as vimba, sea trout, salmon and eel. Very low frequency of these species proves the huge impact the Wloclawek dam has had on these populations by drastically limiting the migration possibilities of these fish.

7. Alien species also constitute a constant component of the Warsaw ichthyofauna. The species, such as bighead carp and stone moroco have reached Warsaw water bodies as a result of deliberate or accidental stockings, or originate from the Dnieper river basin (goad goby, Caspian sand goby). The migration of these species was made possible by the construction of the Bug-Dnieper Canal. At first, American bullhead was raised in some pond farms, from where it has reached the rivers and lakes (Brylińska 2000). Still not enough is known on the way amur sleeper use to reach Warsaw water bodies.

8. The fish species assemblage that inhabits the Vistula River contains 3 species less than the ichthyofauna in the inter-war period.

9. Constant monitoring of the ichthyofauna of Warsaw water bodies is important to enrich the knowledge on fish species that inhabit water bodies in Warsaw. 


\section{REFERENCES}

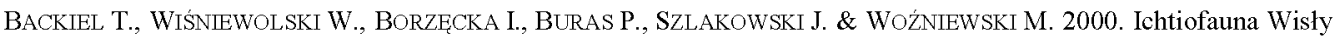
od ujścia Pilicy do ujścia Narwi. In: MATUSzKIEWICZ J. M., ROO-ZIELIŃSKA E. (eds), Międzywale Wisły jako swoisty układ przyrodniczy (odcinek Pilica-Narew). PAN Instytut Geografii i Przestrzennego Zagospodarowania Warszawa, Dokumentacja Geograficzna 19: 97-105.

BALON E. K. 1975. Reproductive guilds of fishes - a proposal and definition. Journal of the Fisheries Research Board of Canada 32: 821-864.

BONTEMPS S. \& RUDNICKI A. 1968 (manuscript). Ichtiofauna górnego odcinka rzeki Narwi. Instytut Rybactwa Śródlądowego, Żabieniec, 12 pp.

BORZĘCKA I., WIŚNIEWOLSKI W., SZLAKOWSKI J. \& BURAS P. 2003 (manuscript). Ocena zespolów ryb jeziorka Szczęśliwice. Polski Związek Wędkarski, Okręg Mazowiecki, Warszawa, 10 pp.

BRYLIŃSKA M. (ed.). 2000. Ryby słodkowodne Polski. PWN, Warszawa, 521 pp.

DANILKIEWICZ Z. 1997. Minogi oraz ryby rzeki Bugu i jego polskich dopływów. Archiwum Rybactwa Polskiego 5 (Supl. 2): 5-82.

FIC M. \& KREGEL J. 2004. Warunki geomorfologiczne i hydrograficzne w rejonie jeziorka Czerniakowskiego. In: FIC M. (ed.): Ekofizjograficzno-urbanistyczne uwarunkowania zagospodarowania rejonu Jeziorka Czerniakowskiego w Warszawie - wybrane zagadnienia. IMUZ Falenty: 57-67.

KRUK A., SZYMCZAK M. \& SPYCHALSKI P. 2003. Ichtiofauna miasta Lodzi. Part I. Dorzecza Jasienia i Łódki. Roczniki Naukowe Polskiego Związu Wędkarskiego 16: 79-96.

KRUK A., SPYCHALSKI P. \& GALICKA W. 2005. Ichtiofauna miasta Lodzi. Part II. System Sokolówki. Roczniki Naukowe PZW 18: 29-46.

MATUSZKIEWICZ J. M. 2000. Założenia kompleksowych badań przyrodniczych międzywala Wisły na odcinku warszawskim. In: MATUSZKIEWICZ J. M., Roo-ZIELIŃSKA E. (eds), Międzywale Wisły jako Swoisty układ przyrodniczy (odcinek Pilica-Narew). PAN Instytut Geografii i Przestrzennego Zagospodarowania Warszawa, Dokumentacja Geograficzna 19: 7-15.

NABIALEK J. 1984. Wpływ ciepłych wód zrzutowych z elektrowni Kozienice na ichtiofaunę przybrzeżnej strefy Wisły. Roczniki Nauk Rolniczych, Seria H, 100 (4): 83-109.

OPUSZYŃSKI K. 1983. Podstawy biologii ryb. 2nd ed. PWRiL, Warszawa 590 pp.

PENCZAK T. 1988: Ichtiofauna dorzecza Pilicy. I. Przed utworzeniem zbiornika. Roczniki Naukowe Polskiego Związku Wędkarskiego 1: 25-59.

PENCZAK T., Koszalinski H., BuCzyisska M. \& JAKUCEWICZ H. 1990a. Ichtiofauna dorzecza Narwi. I. Narew. Roczniki Naukowe Polskiego Związku Wędkarskiego 3: 81-94.

Penczak T., ManN R. K. H., Koszalński H. \& PIETROwska M. 1990b. Ichtiofauna dorzecza Narwi. II. Pisa i jej dopływy. Roczniki Naukowe Polskiego Związku Wędkarskiego 3: 95-114.

PENCZAK T., ZaCzYNiski A., Koszalí́ski H., GaliCKa W., Ułańska M. \& Koszalnjska M. 1991a. Ichtiofauna dorzecza Narwi. III. Supraśl i inne rzeki Wysoczyzny Białostockiej. Roczniki Naukowe Polskiego Związku Wędkarskiego 4: 65-81.

PENCZAK T., ZACZYŃSKi A., KoSZALIŃSKi H., KOSZALIŃSKA M. \& UEAŃSKA M. 1991b. Ichtiofauna dorzecza Narwi. IV. Lewobrzeżne doplywy Narwi. Roczniki Naukowe Polskiego Związku Wędkarskiego 4: 83-99.

Penczak T., Koszaliński H., Zacziński A., Koszalinska M. \& UŁańsKa M. 1992. Ichtiofauna dorzecza Narwi. V. Rzeki Równiny Kurpiowskiej. Roczniki Naukowe Polskiego Związku Wędkarskiego 5: 155-172.

Penczak T., KruK A., Koszaliński H. \& ZiĘBA G. 2000. Ichtiofauna rzeki Bzury. Roczniki Naukowe Polskiego Związku Wędkarskiego 13: 23-33.

PRUS P. 2004. Charakterystyka hydrobiologiczna jeziorka Czerniakowskiego. In: FIC M. (ed.): Ekofizjograficznourbanistyczne uwarunkowania zagospodarowania rejonu Jeziorka Czerniakowskiego w Warszawie - wybrane zagadnienia. Instytut Melioracji I Użytków Zielonych, Falenty: 40-53.

SCHEMER F. \& WADBACHER H. 1992. Strategies for conservation of a Danubian fish fauna. In: BOON P. J., CALOW P. \& PETTS G. E. (eds), River Conservation and Management, pp. 363-382. John Wiley and Sons, Chichester, 470 pp.

SUMMísKi S. M. \& TENENBAUM S. 1921. Przewodnik zoologiczny po okolicach Warszawy. Wydawnictwo M. Aret Warszawa, $100 \mathrm{pp}$.

SUMMŃSKI S. M. 1922. Fauna Warszawy. Ziemia. 7 (12): 328-335.

SYCH R., NABIAEEK J. \& WIŚNIEWOLSKI W. 1990. Ocena rybackiego znaczenia górnej Narwi. Nauka i Praktyka. Studia-Ekspertyzy-Informacje. 1'90. Ośrodek Badań Naukowych w Białymstoku: 179-196.

WIŚNIEWOLSKI W., SZLAKOWSKI J., BIAEOKOZ W., CHYBOWSKI L. \& BORZĘCKA I. 1999 Ichtiocenozy Lomżyńskiego Parku Krajobrazowego Doliny Narwi: stan i zagrożenia. Łomżyński Park Krajobrazowy, Drozdowo, 27 pp.

WIŚNIEWOLSKI W. 2005 (manuscript). Ocena możliwości prowadzenia gospodarki rybacko-wędkarskiej w zbiornikach wodnych na terenie Warszawy. Polski Związek Wędkarski, Okręg Mazowiecki, Warszawa, 6 pp.

Wiśnewolski W., Szlakowski J., BuRAs P., Borzęcka I., Wolos A. \& PruS P. 2004a. Ichtiofauna Narwiańskiego Parku Narodowego. In: BANASZUK H. (ed.), Przyroda Podlasia. Narwiański Park Narodowy. Wydawnictwo Ekonomia i Srodowisko, Białystok: 320-330. 
WIŚNIEWOLSKI W., SZLAKOWSKI J., BURAS P. \& KLEIN M. 2004b. Ichtiofauna Biebrzańskiego Parku Narodowego. In: BANASzUK H. (ed.), Kotlina Biebrzańska i Biebrzański Park Narodowy. Wydawnictwo Ekonomia i Środowisko, Bialystok: 455-489.

WiTKowsKi A. 1984. Analiza ichtiofauny basenu Biebrzy. II. Materialy do znajomości rybostanu i przegląd gatunków. Fragmenta Faunistica, 28: 137-184.

WitKowski A., KotUsz J. \& PRZYBYLSKi M. 2009. Stopień zagrożenia słodkowodnej ichtiofauny Polski: Czerwona lista minogów i ryb - stan 2009. Chrońmy Przyrodę Ojczystą 65: 33-52.

\section{STRESZCZENIE}

\section{[Ichtiofauna wybranych zbiorników wodnych i Wisly na obszarze Warszawy]}

Celem pracy było opisanie ichtiofauny zasiedlajacej wody Warszawy. Opisano ichtiofaune warszawskiego odcinka Wisly (od $\mathrm{km} 506$ do 525) oraz polożonych na terenie miasta zbiorników - Jeziorko Czerniakowskie (19,5 ha), Jeziorko Szczęśliwickie (6,0 ha), Jeziorko Kamionkowskie ( 8,0 ha), Jeziorko Wilanowskie (15,0 ha), Jeziorko Powsinkowskie (8,5 ha). Informacje pochodzily z odłowów kontrolnych (elektryczne i sieciowe), zapisów protokolów zarybieniowych oraz wywiadów z wędkarzami. Klasyfikację taksonomiczną gatunków przyjęto wg Nelsona (Brylińska 2000). Gatunki przyporządkowano do ekologicznych grup: rozrodczych, troficznych, przeplywu wody. Łącznie w warszawskich wodach stwierdzono 40 gatunków ryb. W Wiśle 33, natomiast w jeziorkach od 3 do 11 gatunków. Wśród gatunków z Wisly reprezentowane byly wszystkie wydzielone grupy ekologiczne. W jeziorkach brak było gatunków reofilnych oraz litofilnych i psammofilnych. W warszawskich wodach występuja gatunki objęte ochroną gatunkową (różanka, piskorz, kielb bialopletwy, śliz), chronione w ramach europejskiej sieci ekologicznej Natura 2000 (boleń, kiełb bialopletwy, piskorz, różanka, losoś), diadromiczne gatunki ryb wędrownych (certa, troć wędrowna, losoś, węgorz) oraz gatunki obce (tolpyga pstra, czebaczek amurski, babka lysa, babka szczupla, sapa). 